\title{
Система кондиціювання повітря на основі випарного охолодження i відкритого абсорбційного циклу
}

\author{
Ю. І. Дем'яненко ${ }^{1 凶}$, О. В. Дорошенко ${ }^{2}$, М. І. Гоголь ${ }^{3}$ \\ $1,2,3$ Одеська національна академія харчових технологій, вул. Канатна, 112, Одеса, 65039, Україна \\ $\triangle$ e-mail: ${ }^{1}$ dejurij@gmail.com
}

\begin{abstract}
У наш час дефіџит енергії і охорона навколишнього середовища змушують господарників і проектувальників систем кондиціювання до пошуку інших, непарокомпресійних джерел холодопостачання. В статті запропонована система кондиціювання повітря, яка використовує природну нерівноважність атмосферного повітря - психрометричну різницю температур. Проаналізовані процеси прямого та непрямого випарного охолодження повітря стосовно досягнення комфортної зони. На h,d- діаграмі показано, щз в результаті прямого випарного охолодження можна досягти області комфорту. Відмічено, що визначальний вплив на ефективність процесу випарного охолодження має вологовміст повітря на вході в апарат. В регіонах, де він високий, вирішальну роль відіграє попереднє осушення повітря. Запропонована альтернативна установка кондиціювання повітря на основі випарного охолодження і попереднього осушення повітря, завдяки чому збільшується психрометрична різниия температур повітря та стає можсливим вийти в комфортну зону без застосування парокомпресійного холодильного цииклу. Осушення повітря відбувається в абсорбері розчином бромістого літію, для регенерачії якого використовується тепло, щьо виробляється сонячними колекторами. 3 огляду на те, щуо в прочесі абсорбиї температура абсорбенту зростає, в схемі передбачено відведення теплоти абсорбиії водою, попередньо охолодженою в градирні. Поставлено задачу досягти після установки стану повітря, близького до температури точки роси, збільшивши таким чином ї̈ холодопродуктивність. При изому слід забезпечити зменшення габаритів установки та витрат енергії на переміщення контактуючих потоків повітря, води та розчину абсорбенту. Всі тепломасообмінні апарати в установиі виконані за поперечною схемою на основі регулярної насадки. Такий підхід дозволив мінімізувати аеродинамічний опір апаратів та їх габарити. Розроблена схема сонячної системи кондичіювання повітря (ССКП) запропонована для кондииіювання одного із супермаркетів.
\end{abstract}

Ключові слова: Сонячна система кондииіювання повітря; Випарне охолодження; Абсорбиія; Десорбиія; Сонячні колектори

doi: https://doi.org/10.15673/ret.v56i1-2.1824

(c) The Author(s) 2020. This article is an open access publication

This work is licensed under the Creative Commons Attribution 4.0 International License (CC BY) http://creativecommons.org/licenses/by/4.0/

\section{1. Вступ}

У наш час дефіцит енергії і охорона навколишнього середовища змушують господарників і проектувальників систем кондиціонування до пошуку інших, непарокомпресійних джерел холодопостачання. Це дозволяє уникнути не тільки забруднення атмосфери, але і знизити енергоспожи- вання.

Найбільшої уваги заслуговує випарне охолодження повітря (води), рушійною силою якого $\epsilon$ природна нерівноважність атмосферного повітря психрометрична різниця температур.

Проте остання $є$ функцією тепловологісних параметрів повітря і суттєво відрізняється за регіонами (таблиця 1). 
Таблиця 1 - Параметри зовнішнього повітря та психрометрична різниця температур для деяких міст Украӥни (теплий період)

\begin{tabular}{|c|c|c|c|c|c|c|c|c|}
\hline \multirow{2}{*}{ Місто } & \multicolumn{7}{|c|}{ Параметри зовнішнього повітря } \\
\cline { 2 - 10 } & \multicolumn{9}{|c|}{ Б } & \multicolumn{2}{|c|}{ В } \\
\cline { 2 - 9 } & $t,{ }^{\circ} \mathrm{C}$ & $\begin{array}{c}h, \\
\text { кДж/кг }\end{array}$ & $d, \Gamma /$ кг & $t_{\mathrm{M}},{ }^{\circ} \mathrm{C}$ & $\begin{array}{c}d_{\mathrm{M}}, \\
\Gamma / \text { кг }\end{array}$ & $t-t_{\mathrm{M}}$ & $t,{ }^{\circ} \mathrm{C}$ & $\begin{array}{c}h, \\
\text { кДж/кг }\end{array}$ \\
\hline Одеса & 28,6 & 62,0 & 13,0 & 21,3 & 15,9 & 7,3 & 38 & 73,7 \\
\hline Херсон & 30,6 & 61,6 & 12,0 & 21,2 & 15,2 & 9,4 & 39 & 74,6 \\
\hline Київ & 28,7 & 56,1 & 10,6 & 19,6 & 14,3 & 9,1 & 39 & 70,8 \\
\hline Луганськ & 31,8 & 58,7 & 10,4 & 20,3 & 15,0 & 11,5 & 40 & 66,2 \\
\hline Харків & 29,4 & 56,1 & 10,3 & 19,6 & 14,3 & 9,8 & 39 & 76,3 \\
\hline
\end{tabular}

Тому і ефективність апаратів випарного охолодження буде різною. Щоб зробити iі незалежною від зовнішніх умов, пропонується використовувати попереднє осушення атмосферного повітря [1-4], завдяки чому зменшується вологовміст повітря та стає можливим за допомогою випарного охолодження вийти в комфортну зону.

Відомим прототипом $є$ установка охолодження повітря, що складається із абсорбера та випарного повітроохолоджувача непрямого типу (НBO). В абсорбері осушується зовнішне повітря, яке потім надходить у НВО [1].

Недоліками установки є:

- одноступенева схема, що не дозволяє отримати температуру продукційного повітря, що $е$ близькою до точки роси зовнішнього повітря;

- не використовується потенціал холодного допоміжного потоку, який викидається в атмосферу;

- в «мокрих» каналах НВО використовується не осушене повітря, а зовнішнє, що зменшує потенціал рухомих сил процесу.

Також відомим прототипом $є$ сонячна установка кондиціювання повітря на основі відкритого абсорбційного циклу та непрямої регенерації абсорбенту [2].

Їй притаманні такі недоліки:

- границею охолодження повітря є його температура за мокрим термометром;

- всі апарати кожухотрубного типу, що призводить до великих габаритів системи та підвищеного аеродинамічного опору.

\section{2. Постановка проблеми}

Природною межею випарного охолодження води у випарних охолоджувачах є температура повітря за мокрим термометром $t_{\mathrm{M} 1}$ на вході в апарат. На виході із апарату граничною $є$ температура во- ди $t_{\mathrm{B} 1}$, що поступає на охолодження (ентальпія повітря за цієї температури $h_{п}^{2 *}$ ). Ефективність охолодження води $E_{\text {в }}$ і ступінь використання повітря в апараті $E_{\text {п }}$ (відношення тепла, що виноситься із апарату потоком повітря, до граничної його величини, що настає за умови $h_{\text {п }}^{2}=h_{\text {п }}^{2 *}$ ) знаходяться відповідно з виразів:

$$
E_{\mathrm{B}}=\frac{t_{\mathrm{B} 1}-t_{\mathrm{B} 2}}{t_{\mathrm{B} 1}-t_{\mathrm{M} 1}} \quad E_{\mathrm{n}}=\frac{h_{\mathrm{n} 2}-h_{\mathrm{n} 1}}{h_{\mathrm{\pi}}^{2^{*}}-h_{\text {п1 }}}
$$

Визначальний вплив на ефективність процесу випарного охолодження має вологовміст повітря на вході в апарат. В регіонах, де він високий, вирішальну роль відіграє попереднє осушення повітря. Розглянемо це на конкретному прикладі.

Так, адіабатичне охолодження повітря стану 1 (процес 1-4) не дозволяє досягти області комфорту (рис. 1). Але якщо повітря попередньо осушити (процес 1-2), то психрометрична різниця температур зросте і повітря можна буде використовувати для асиміляції тепло- і вологовиділень у приміщенні (рис. 1).

Так, на $h, d$ - діаграмі показано, що в результаті прямого випарного охолодження (процесс 2-3) можна досягти області комфорту, проте точка 3 знаходиться надто близько до верхньої межі комфортної зони і робоча різниця температур не перевищує 2-3 градусів. Такого повітря потрібно надто багато для асиміляції надлишків тепла та вологи в приміщенні.

Поставлено задачу досягти після установки стану повітря, близького до температури точки роси, збільшивши таким чином іiі холодопродуктивність. При цьому слід забезпечити зменшення габаритів установки та витрат енергії на переміщення контактуючих потоків повітря, води та розчину абсорбенту.

Для досягнення поставленої мети було запропоновано тепловологісну обробку повітря прово- 
дити в двох послідовних ступенях: в непрямому та прямому (ПВО) випарних охолоджувачах повітря (рисунок 2). При цьому тепломасообмінні апарати - абсорбер, десорбер, градирня, НВО та ПВО за виконанням $є$ плівкового типу 3 регулярною насадкою; за конструктивну основу взято поперечну схему руху контактуючих потоків повітря та рідини.

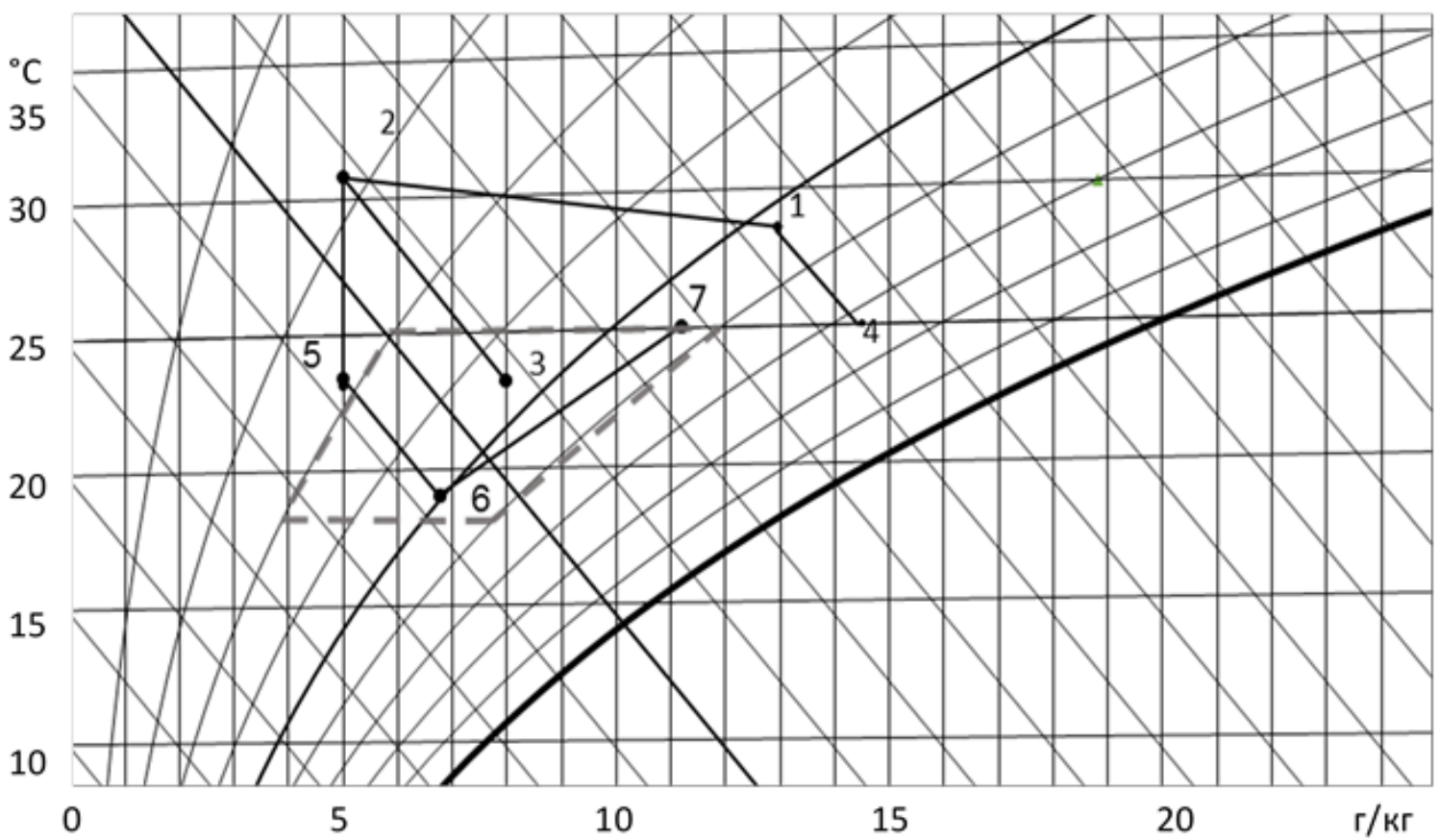

Рисунок 1 - Прочеси в ССКП відносно комфортної зони (відмічена пунктиром). Можливі варіанти обробки атмосферного повітря: 1-4 - пряме випарне охолодження повітря; 1-2 - осушення повітря в абсорбері; 2-3 - пряме випарне охолодження осушеного повітря; 2-5 - непряме випарне охолодження осушеного повітря в непрямому випарному охолоджувачі (НВО); 5-6 - пряме випарне охолодження повітря (ПВО); 6-7 - процес зміни стану повітря в приміщенні

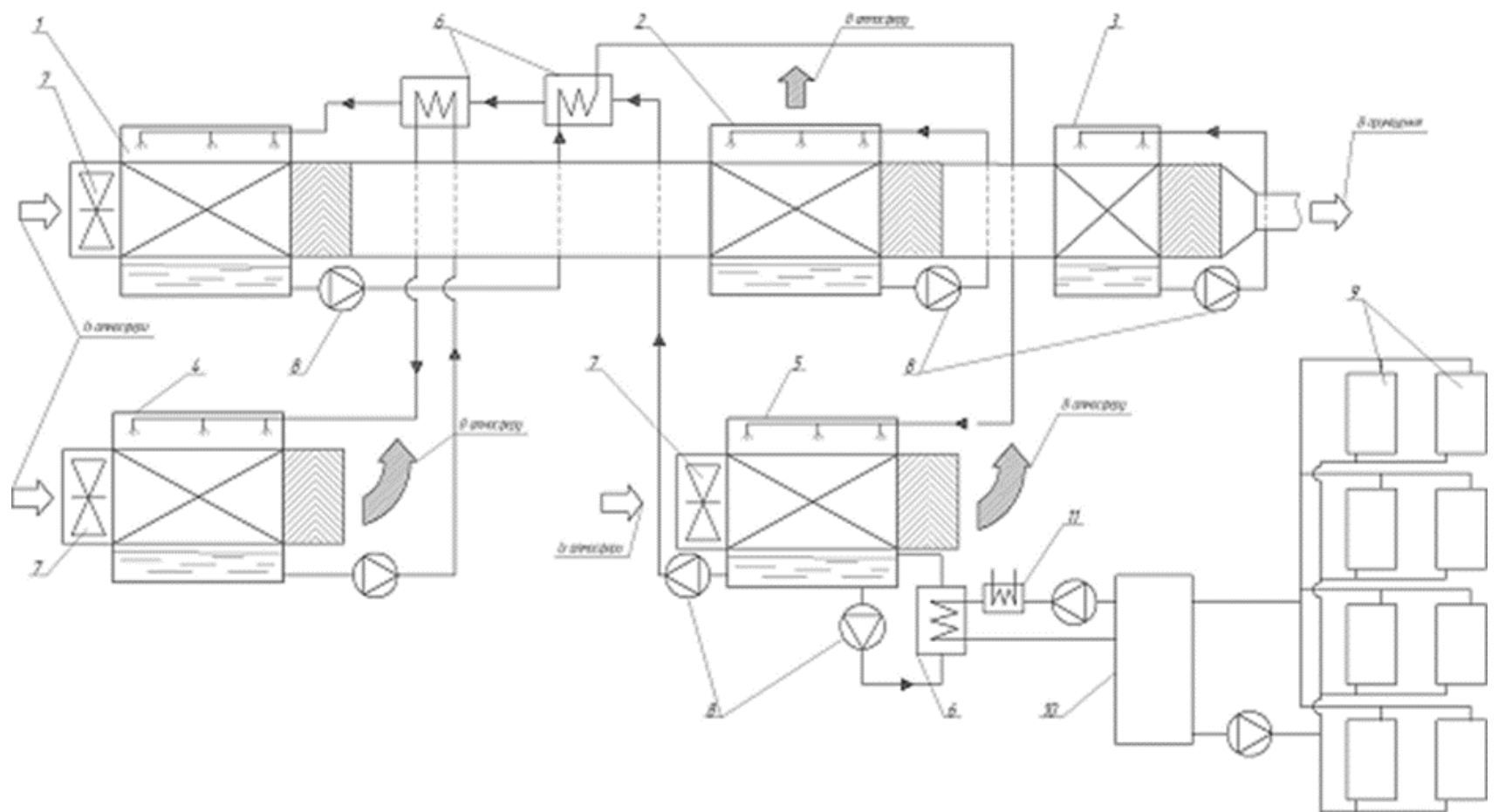

Рисунок 2 - Технологічна схема альтернативної ССКП:

1 -абсорбер; 2 -НВО; 3 - ПВО; 4 - градирня технологічна; 5 -десорбер; 6 - теплообмінники;

7 -вентилятори; 8-насоси; 9-геліополе; 10 -бак-акумулятор; 11 - додаткове джерело тепла 
Дослідження показали, що таке конструктивне рішення дозволяє, в порівнянні з протиточною конструкцією, зменшити габарити апаратів, уникнувши поворотів повітряних потоків, а також i ïx аеродинамічний опір $[3,4]$.

У випадку послідовного застосування непрямого випарного охолодження (2-5) та прямого (5-6), повітря стану 6, надійшовши в приміщення, асимілює надлишки тепла і вологи і виходить 3 приміщення в стані, близькому до верхньої межі комфортної зони (процес 6-7).

Для того, щоб цикл повторився необхідно поновити концентрацію абсорбенту, випаривши із розчину вологу. Для цього доцільно використати десорбер, джерелом тепла для якого буде сонячна енергія. Реалізація такого циклу [5] практично доцільна, його технологічна схема представлена на рис. 2 .

Масові витрати повітря і рідини через всі апарати, крім ПВО, однакові. Як відомо, після НВО (поз.2) допоміжний повітряний потік (приблизно половина) викидається в атмосферу. Тому кількість технологічного повітря, що проходить через абсорбер, десорбер, НВО та технологічну градир- ню, приблизно в два рази більше кількості продуктового повітря, що подається в приміщення.

У разі роботи в умовах забрудненого повітря та високих концентрацій абсорбенту пропонується використання апаратів 3 рухомою псевдозрідженою насадкою «повітря-вода-тверде тіло» з розміщенням у шарі рухомої насадки теплообмінника. Це забезпечує чистоту продуктового потоку та самоочищення насадки і стінок корпусу тепломасообмінного апарату (ТМА).

На основі практики використання рухомої насадки в хімічній промисловості, а також проведених досліджень була прийнята сферична форма насадкових елементів, густина яких знаходиться в діапазоні $\rho_{\text {не }}=300-600 \mathrm{\kappa г} / \mathrm{m}^{3}$.

НВО можуть використовуватись як охолоджувачі не тільки повітря, але і охолоджувачі води. В НВОп (рис. 3А) основний повітряний потік охолоджується без контакту з водою - при незмінному вологовмісті, а допоміжний знаходиться в прямому контакті з водою, що рециркулює через «мокру» частину апарату; при цьому температура води є постійною і дещо більшою від температури атмосферного повітря за мокрим термометром.

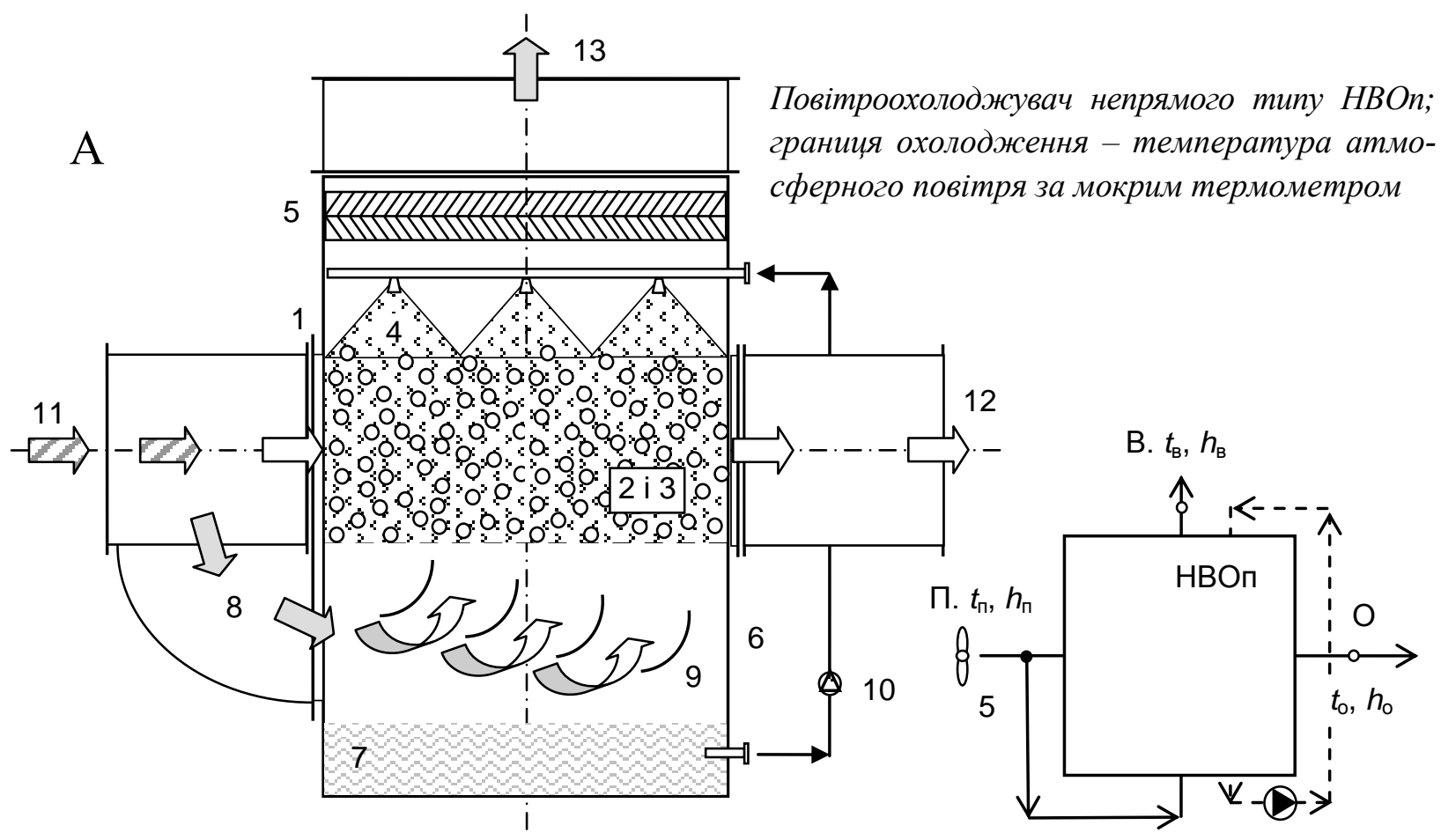

Рисунок 3 - Принципова схема і основні елементи повітроохолоджувачів HBOn (A) i HВО-Р (Б) з рухомою насадкою $\mathrm{PH}$; $B$ - приниипова схема і основні елементи теплообмінника $\mathrm{HBOm} / \kappa$, розміменого безпосередньо в шарі РН. Позначення: 1 -корпус; 2, 3 - робоча камера і теплообмінник основного і допоміжного потоків повітря; 4 - водорозподільник; 5 - сепаратор; 6 - повітророзподільник; 7 - ємність для води; 8, 9 - поворотний дифузор і решітка; 10 -насос; 11, 12 і 13 - повний, основний і допоміжний повітряні потоки 


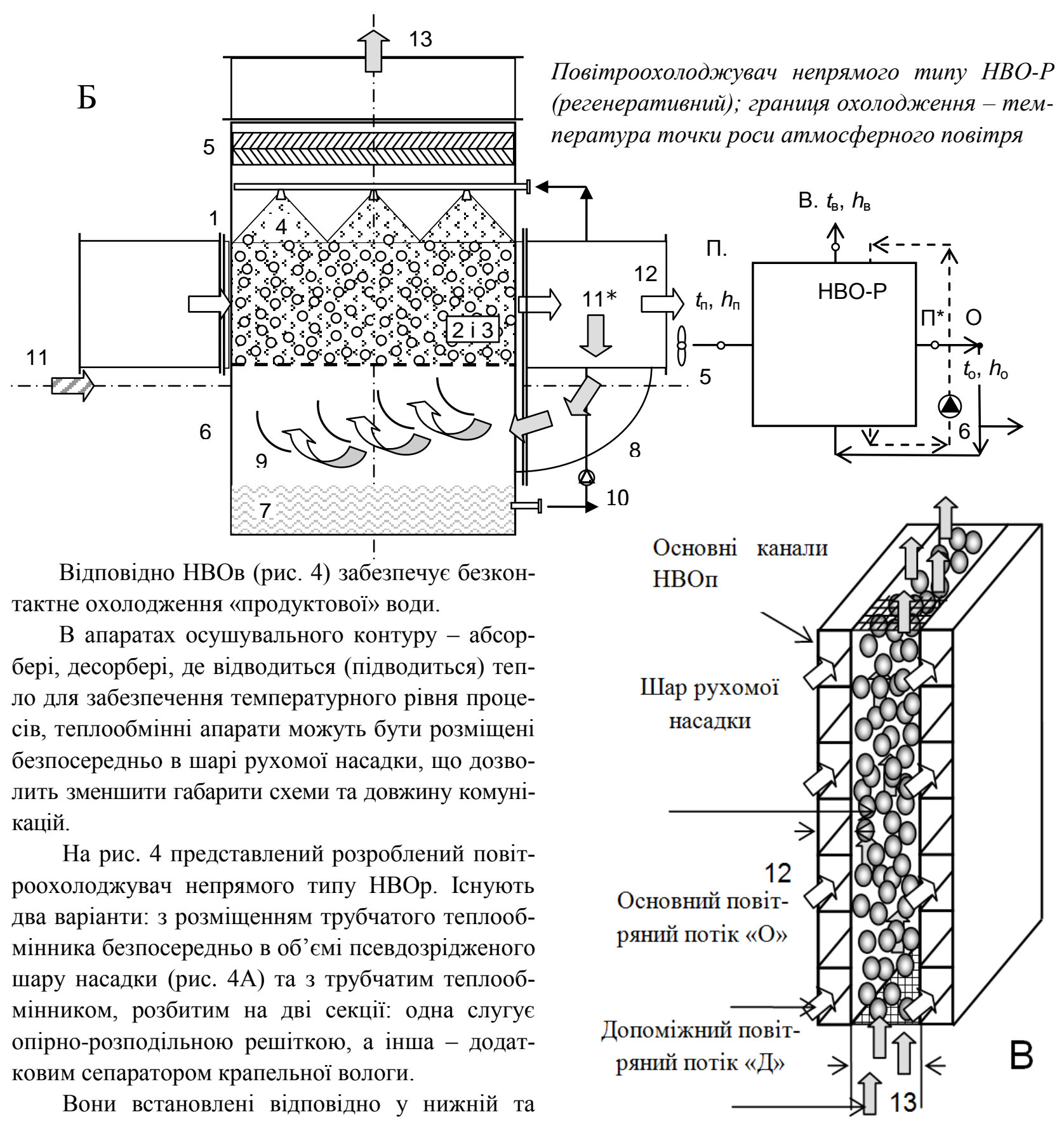
верхній частинах; між ними знаходиться шар рухомої насадки (рис. 4В).

\section{3. Висновки}

3 прив'язкою до конкретного об'єкту (супермаркет площею $21,8 \times 28=610 \mathrm{~m}^{2}$ ) були розраховані характеристики ССКП. Теплове навантаження становило 50,7 кВт.

Встановлені в торговій залі холодильні вітрини мають $Q_{\text {вітр }}=24,2$ кВт сумарну холодопродуктивність. Холодопродуктивність, яку повинна забезпечити система кондиціонування повітря, становить:

$$
Q_{\text {ССКП }}=Q_{\text {тепл }}-Q_{\text {вітр }}=50,7-24,2=26,5 \text { кВт }
$$

Атмосферне повітря в абсорбері осушується від $d_{1}=13$ г/кг до $d_{2}=5$ г/кг (рисунок 1$)$.

Щоб отримати холод в кількості $Q_{\text {сскп }}=26,5$ кВт, витрата повітря крізь ПВО (рис.2) повинна становити:

$$
M=\frac{Q_{\text {ССК }}}{\rho_{\mathrm{B}} \cdot c_{p} \cdot\left(t_{2}-t_{\mathrm{B}}\right)}=\frac{26,5}{1,2 \cdot 1,005 \cdot(32-19)}=1,69 \frac{\mathrm{M}^{3}}{\mathrm{c}}
$$

або $6085 \mathrm{~m}^{3} /$ год; можна сказати, що через абсорбер, десорбер і НВО проходитиме $12170 \mathrm{~m}^{3} /$ год.

Отже, кількість тепла, яке виділяється в абсорбері, складатиме

$Q_{\text {АБР }}=\frac{V_{\text {пов }}}{3600} \cdot \rho_{\text {пов }} \cdot\left(h_{1}-h_{2}\right)=\frac{12170}{3600} \cdot 1,2 \cdot(62-44)=73 \mathrm{\kappa BT}$ 
Оцінюючи теплові втрати в апаратах і комунікаціях як в $10 \%$, отримаємо теплопродуктив- ність СК, необхідну для забезпечення процесу десорбції: $Q_{\mathrm{CК}}=1,1 \cdot 73=80,3$ кВт .

Водоохолоджувач непрямого типу НВОв; граниия охолодження - температура атмосферного повітря за мокрим термометром
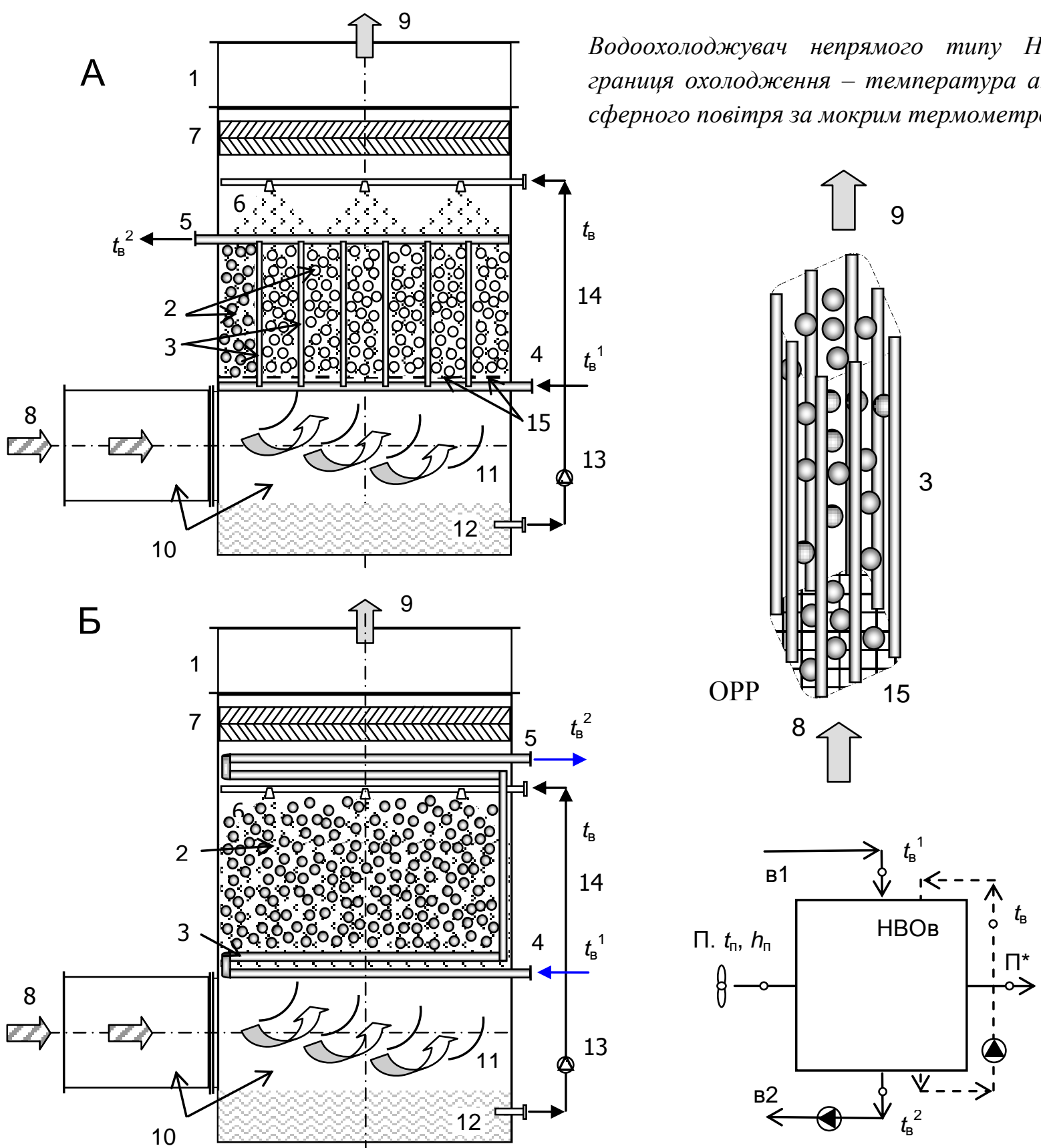

Рисунок 4 - Принципова схема і основні елементи водоохолоджувача НВОв з $\mathrm{PH}$ : A (B) - (варіант 1) об'єм РН з секиіонованими псевдозрідженими шарами насадки між елементами теплообмінника; Б - (варіант 2) об'єм РН, розміщений між секціями теплообмінника, щзо виконують функиії опірнорозподільної решітки (ОРP) і сепаратора крапельної вологи. Позначення: 1 - корпус; 2 - робоча камера; 3 - теплообмінник; 4 і 5 - гідравлічні колектори-розподільники; 6-розподільник рециркулюючої води;

7 -сепаратор; 8 і 9 - повітря, щчо входить і виходить з НВО; 10, 11 - зона повітророзподілу;

12 - ємність; 13 - насос; 14 - контур рециркулящії; 15 -ОРР

ССКП працює 12 годин (з 8.00 до 20.00) з коефіцієнтом робочого часу 0,7 , тобто 8,4 години на добу. Енергія десорбції становитиме:

$$
Q_{\mathrm{CK}}^{\mathrm{E}}=80,3 \cdot 8,4=674,52 \text { кВТ } \cdot \text { год }
$$

Необхідна площа СК за умови, що ккд $\eta=0,7$, складе:

$$
F_{\mathrm{CK}}=\frac{Q_{\mathrm{CK}}^{\mathrm{E}}}{\eta \cdot q_{\mathrm{paд}}}=\frac{674,52}{0,7 \cdot 6,18}=155,9 \mathrm{M}^{2}
$$




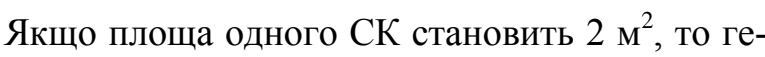
ліополе супермаркету міститиме 78 сонячних колекторів.

Авторами була проведена попередня технікоекономічна оцінка застосування такої ССКП порівняно з чілером; холодопродуктивність в обох випадках становила 30 кВт. Встановлено, що сумарна електрична потужність вентиляторів і насосів в схемі ССКП становить 53\% від потужності, споживаної чілером, а термін окупності за існуючих тарифів на електроенергію дорівнює 4 рокам. Але найголовнішою обставиною $\epsilon$ відсутність озоноруйнуючих фреонів, а, отже, зменшення техногенного впливу на навколишнє середовище.

\section{Література}

1. W. Z. Gao, Y. P. Cheng et al. Experimental investigation on integration liquid desiccant - indirect evaporative air cooling system utilizing the Maisotesenko - Cycle // Applied Thermal Engineering. 2015. - Vol. 88. - P. 288-296.
2. Hellman H. M., Grossman G. Simultation and analysis of an open-cycle dehumidifier-evaporator (DER) absorption chiller for low-grade heat utilization // International Journal of Refrigeration. - 1995. Vol. 18. - № 3. - P. 177-189.

3. Дорошенко О. В. Компактна тепломасообмінна апаратура для холодильної і кріогенної техніки (Теорія та інженерна практика). Дисертація. Україна, Одеса: Одеський технологічний інститут холодильної промисловості, 1988. - 222 с.

4. Дорошенко А. В, Антонова А. Р., Демьяненко Ю. И. Солнечные многоступенчатые абсорбционные холодильные системы на основе тепломассообменных аппаратов пленочного типа // Холодильная техника и технология. - 2016. - 51(2) C. 25-31.

5. Дорошенко О. В., Дем'яненко Ю. І., Колодяжний В. В. Установка кондиціювання повітря. Патент на корисну модель № 116534, F 280 5/02 F 24F 1/00. - Бюл. № 10. - 25.05.2017.

Отримана в редакції 12.02.2020, прийнята до друку 03.03.2020

\title{
Air conditioning system based on evaporative cooling and open absorption cycle
}

\author{
Yu. Demyanenko ${ }^{1 \bowtie}$, O. Doroshenko ${ }^{2}$, M. Gogol $^{3}$ \\ ${ }^{1,2,3}$ Odessa National Academy of Food Technologies, 112 Kanatna str., Odessa, 65039, Ukraine \\ $\triangle$ e-mail: ${ }^{1}$ dejurij@gmail.com
}

Nowadays, energy shortages and environmental protection are forcing owners and designers of air conditioning systems to look for other, non-steam compression sources of refrigeration. The article proposes an air conditioning system that uses the natural imbalance of atmospheric air-psychrometric temperature difference. The processes of direct and indirect evaporative cooling of air in relation to achieving a comfort zone are analyzed. The $h, d$-diagram shows that as a result of direct evaporative cooling, a comfort region can be achieved. It is noted that the decisive influence on the efficiency of the evaporative cooling process has the moisture content of the air at the entrance to the apparatus. In regions where it is high, pre-dehumidification plays a crucial role. An alternative air conditioning system based on evaporative cooling and pre-dehumidification is proposed, which increases the psychrometric difference in air temperature and makes it possible to enter the comfort zone without the use of a steam-compression refrigeration cycle. Dehumidification of air takes place in the absorber with a solution of lithium bromide, for the regeneration of which the heat produced by solar collectors is used. Due to the fact that in the process of absorption the temperature of the absorbent increases, the scheme provides for the removal of heat of absorption by water pre-cooled in the cooling tower. The task is to achieve after setting the state of the air close to the temperature of the dew point, thus increasing its cooling capacity. At the same time it is necessary to provide reduction of dimensions of installation and expenses of energy for movement of contact streams of air, water and an absorbent solution. All heat and mass exchangers in the installation are made according to the transverse scheme on the basis of a regular nozzle. This approach allowed to minimize the aerodynamic drag of the devices and their dimensions. The developed scheme of the solar air conditioning system (SPS) is proposed for the conditioning of one of the supermarkets.

Keywords: Solar air conditioning system; Evaporative cooling; Absorption; Desorption; Solar collectors 


\section{References}

1. Gao, W. Z., Cheng, Y. P. et al. (2015) Experimental investigation on integration liquid desiccant indirect evaporative air cooling system utilizing the Maisotesenko - Cycle. Applied Thermal Engineering, 88, 288-296.

2. Hellman, H. M., Grossman, G. (1995) Simultation and analysis of an open-cycle dehumidifier-evaporator (DER) absorption chiller for low-grade heat utilization. International Journal of Refrigeration, 18 (3), 177-189.

3. Doroshenko, O. V. (1988) Compact heat and mass transfer equipment for refrigeration and cryogenic equipment (Theory and engineering practice). Disser- tation. Ukraine, Odessa: Odessa Technological Institute of Refrigeration Industry, 222.

4. Doroshenko, A. V, Antonova, A. R., Demyanenko, Yu. I. (2016) Solar multistage absorption refrigeration systems based on heat and mass transfer apparatus of film type. Refrigeration engineering and technology, 51 (2), 25-31.

5. Doroshenko, O.V., Demyanenko, Yu. I., Kolodyazhny, V.V. (2017) Installation of air conditioning. Utility model patent № 116534, F 280 5/02 F 24F 1/00, Bull. № 10.

Received 12 February 2020

Approved 03 March 2020

Available in Internet 04 July 2020 